http://jmscr.igmpublication.org/home/ ISSN (e)-2347-176x ISSN (p) 2455-0450

crossref DOI: https://dx.doi.org/10.18535/jmscr/v8i5.13

Journal Of Medical Science And Clinical Research

\title{
Correlation of Urine Cytology for Urothelial Carcinoma as per Paris System with Histopathology
}

\author{
Authors \\ Dr Aditya Jamwal ${ }^{1}$, Dr Sudarshan Kumar Sharma ${ }^{2}$, Dr Neelam Sharma ${ }^{3}$, \\ Dr Pamposh Raina ${ }^{4}$, Dr Anjali Mahajan ${ }^{5}$ \\ ${ }^{1}$ Junior Resident, Department of Pathology \\ ${ }^{2}$ Professor and Head of Department, Department of Pathology \\ ${ }^{3}$ Professor, Department of Pathology \\ ${ }^{4}$ Professor and Head of Department, Department of Urology \\ ${ }^{5}$ Associate Professor, Department of Preventive and Social Medicine \\ *Corresponding Author \\ Dr Sudarshan Kumar Sharma
}

\begin{abstract}
Objectives: This study aims to evaluate the diagnostic accuracy of urine cytology for urothelial carcinomas as per the Paris System and its histopathological correlation.

Methods: A cross-sectional study was conducted over 1 year (July 2018 - June 2019). The study population comprised patients presenting with haematurialdysuria and had radiological findings suggestive of bladder tumor. Preoperative, early morning, midstream, voided urine samples were collected and processed for three consecutive days. The cytospin smears were stained with Papanicolaou stain and reported as per the Paris system. These results were then correlated with gold standard test i.e. Histopathology of TURBT as per WHO classification $2016^{(4)}$. Relevant statistical tests were utilized for data analysis.

Results: 40 cases were studied. According to the reporting criteria of the Paris System, $62.5 \%$ cases were positive for malignancy and $37.5 \%$ cases were negative for malignancy. On histopathology, $82.5 \%$ cases were positive for urothelial carcinoma and $17.5 \%$ cases were negative for urothelial carcinoma. The sensitivity of urine cytology was calculated to be $75 \%$, specificity of urine cytology was $87.5 \%$ and the positive predictive value was $96 \%$.

Conclusion: Urine Cytology as reported by the Paris System will lead to uniform and unequivocal reporting of urothelial carcinoma.
\end{abstract}

\section{Introduction}

The incidence of bladder cancer is ranked $11^{\text {th }}$ in global cancer statistics and seventh in malignancy for male tumors ${ }^{(1)}$. Among urogenital tumors, it is only second to prostate cancer with significant morbidity and mortality. The presence of neoplastic cells in urine was first described by
Sanders in as early as $1864^{(5)}$. However, urinary oncocytology gained popularity when Papanicolaou and Marshall in 1945 mentioned it in a publication ${ }^{(5)}$.

Urine cytology has high sensitivity for detection of high grade urothelial carcinoma and thus it compliment cystoscopic examination. There is no 
doubt that cystoscopy with biopsy is gold standard for diagnosis of UC but it is an invasive procedure and cystoscopy has several limitations as a diagnostic method, more so for flat urothelial lesions $^{(2)}$.

The main purpose of urine cytology is to detect high grade urothelial carcinoma. With this principle in mind The Paris System (TPS) Working group proposed a standardized reporting system in 2013.It also included specific diagnostic categories and cytomorphological criteria for reliable diagnosis of HGUC. So, In late 2015, the consensus group published their guidelines, known as The Paris System (TPS) for reporting urine cytology. ${ }^{(3)}$

\section{Material and Methods}

A cross-sectional study was conducted over 1 year (July 2018 - June 2019). The study population comprised patients presenting with haematuria/dysuria and had radiological findings suggestive of bladder tumor. Preoperative, early morning, midstream, voided urine samples were collected and processed for three consecutive days. The cytospin smears were stained with Papanicolaou stain and reported as per the Paris system. These results were then correlated with gold standard test i.e. Histopathology of TURBT as per WHO classification $2016^{(4)}$. Test thresholds were selected for cytology and histopathology. Relevant statistical tests were utilized for data analysis.

\section{Selections of thresholds for reporting}

Since multiple diagnostic categories were present on cytology as per the Paris System so we used SHGUC (Suspicious for High Grade Urothelial carcinoma) as threshold for considering urine cytology to be positive. Both the categories SHGUC (Suspicious for High Grade Urothelial Carcinoma) and HGUC (High Grade Urothelial carcinoma) had similar cytologic criteria regarding cellular morphology and differed only with respect to variation in cellularity.

The other categories under the Paris System i.e. NHGUC (Negative for High Grade Urotheliual carcinoma), AUC (Atypical Urothelial cells), LGUN (Low Grade Urothelial neoplasm) and Non diagnostic, clearly denotes the absence of morphologically high grade/ malignant cells, hence, in this study these categories are grouped together and considered negative for malignancy, as shown in table no.1.

Table no. 1. Cytology categories as per selected threshold

\begin{tabular}{|l|l|}
\hline $\begin{array}{l}\text { Urine } \\
\text { cytology } \\
\text { results }\end{array}$ & $\begin{array}{l}\text { Diagnostic categories as per selected } \\
\text { threshold }\end{array}$ \\
\hline $\begin{array}{l}\text { Positive for } \\
\text { Malignancy }\end{array}$ & - $\begin{array}{l}\text { Suspicious for High grade carcinoma } \\
\text { (SHGUC) }\end{array}$ \\
\hline $\begin{array}{l}\text { High grade Urothelial Carcinoma } \\
\text { (HGUC) }\end{array}$ \\
\hline $\begin{array}{l}\text { Negative } \\
\text { for } \\
\text { malignancy }\end{array}$ & $\begin{array}{l}\text { Atypical Urothelial cells(AUC) } \\
\text { Negative for high grade urothelial } \\
\text { carcinoma (NHGUC) }\end{array}$ \\
& $\begin{array}{l}\text { Low grade urothelial neoplasm } \\
\text { (LGUN) }\end{array}$ \\
\hline
\end{tabular}

The histological condition was assessed whether histological high grade morphology was present or absent. The selection of threshold of high grade in histopathology was according to WHO classification 2016 as shown in table no. 2 .

Table no. 2. Diagnostic categories in Histopathology as per selected threshold

\begin{tabular}{|l|ll|}
\hline $\begin{array}{l}\text { Histopathologic } \\
\text { results }\end{array}$ & $\begin{array}{l}\text { Diagnostic histopathology categories } \\
\text { considered as per threshold }\end{array}$ \\
\hline $\begin{array}{l}\text { Positive for } \\
\text { Urothelial Carcinoma }\end{array}$ & $\bullet \begin{array}{l}\text { Infiltrating } \\
\text { carcinoma. } \\
\text { High Grade Papillary Urothelial } \\
\text { Carcinoma. } \\
\text { Urothelial Carcinoma }\end{array}$ & $\begin{array}{l}\text { Low Grade Papillary Urothelial } \\
\text { Carcinoma. }\end{array}$ \\
\hline $\begin{array}{l}\text { Papillary Urothelial Neoplasm } \\
\text { of Low Malignant Potential }\end{array}$ \\
$\qquad \begin{array}{l}\text { Inverted Papilloma. } \\
\text { Benign (cystitis, reactive } \\
\text { change) }\end{array}$ \\
\hline
\end{tabular}

\section{Results}

40 cases were studied. According to the reporting criteria of the Paris System, 62.5\% cases were positive for malignancy and $37.5 \%$ cases were negative for malignancy as in table no. 3. On histopathology, $82.5 \%$ cases were positive for urothelial carcinoma and $17.5 \%$ cases were 
negative for urothelial carcinoma as shown in table no. 4. The sensitivity of urine cytology was calculated to be $75 \%$, specificity of urine cytology was $87.5 \%$, the positive predictive value was $96 \%$ as shown in table no. 5 .

Table no. 3. Number of cases as per selected threshold for urine cytology.

\begin{tabular}{|l|c|c|}
\hline Categories & $\begin{array}{c}\text { No. of cases } \\
(\mathrm{n}=40)\end{array}$ & Percentage \\
\hline Positive for Malignancy & 25 & 62.5 \\
\hline Negative for Malignancy & 15 & 37.5 \\
\hline
\end{tabular}

Table no. 4. Number of Histopathology cases as per selected threshold

\begin{tabular}{|l|c|c|}
\hline Categories & $\begin{array}{c}\text { No. of cases } \\
(\mathrm{n}=40)\end{array}$ & Percentage \\
\hline $\begin{array}{l}\text { Positive for Urothelial } \\
\text { Carcinoma }\end{array}$ & 33 & 82.5 \\
\hline $\begin{array}{l}\text { Negative for Urothelial } \\
\text { Carcinoma }\end{array}$ & 7 & 17.5 \\
\hline
\end{tabular}

Table .5. Statistical analysis in this study

\begin{tabular}{|l|c|}
\hline Sensitivity & $75 \%$ \\
\hline Specificity & $87.5 \%$ \\
\hline Positive Predictive Value & $96 \%$ \\
\hline Negative Predictive Value & $46.6 \%$ \\
\hline
\end{tabular}

\section{Discussion}

Urine contains cells that are exfoliated from entire urinary tract. Thus, urine cytology is a noninvasive and inexpensive test for detection of Urothelial Carcinoma compared to histopathology. Over the years, several investigators have published classification schemes for urine cytology and first classification was given by Papanicolaou and Marshall in $1945^{(5)}$. Following this Koss gave a classification which was based on 1973 WHO classification of bladder tumors. He very nicely dealt with the problem faced by Papanicolaou on atypical cells and mentioned the morphological changes seen in atypical cells.

More recently in1984, Murphy and colleagues gave a classification that described Grades of tumors on the basis of morphological changes in tumor cells but he found it difficult to separate low grade lesion from reactive change ${ }^{(5)}$.

\section{Age and Sex distribution}

The mean age for urothelial carcinoma in various studies ranged from 62 to 69 years. In our study also the mean age for UC was found to be 65 years similar to different studies.

In all the studies there has been male preponderance in cases of urothelial carcinoma. In literature, Male to Female ratio ranged from 2-7 :1 and in present study also there is male preponderance with M:F ratio of $4.7: 1$.

\section{Urine Cytology Result}

In different studies the percentage of cases diagnosed as HGUC varied widely from $11.1 \%$ to $38.8 \%$. In our study we found $35 \%$ of cases as HGUC and this finding was similar to observation of Soumitra Das et al ${ }^{(6)}$.

In literature for category SHGUC, cytologically there has been a wide variation in proportion of cases under this category i.e. from $6 \%$ to $27.7 \%$ and in present study $27.5 \%$ cases were diagnosed under this category which was close to observation of Soumitra Das et $\mathrm{al}^{(6)}$.

Similarly, proportion of cases under category NHGUC ranged from $13.8 \%$ to $52.2 \%$. In our study only $12.5 \%$ cases were under this category. Such a variation can be explained partially by relatively small sample size.

On cytological examination no case of LGUN was found in our study and in other studies also LGUN was uncommon as shown in table 10. However in one study (Sharada Rai et $\mathrm{al}^{(7)} 5.6 \%$ of cases were under this category.

Similarly in the literature, cases under AUC category ranged from $11 \%$ to $26 \%$ and in our study it was $22.5 \%$ which is well within this range.

\section{Histopathology Result}

In present study LGUC comprised minority of cases i.e. $20 \%$. In different studies LGUC cases ranged from $19.4 \%$ to $26.8 \%$. However, for HGUC category Mohannad Hassan et $\mathrm{al}^{(9)}$ and Sharada Rai et al $^{(7)}$ found the percentage of cases of HGUC on histopathology to be $56 \%$ and $40 \%$ respectively. Somaye zare et al $^{(8)}$ and Soumitra 
das et $\mathrm{al}^{(6)}$ has relatively lesser number of HGUC cases i.e. $26.3 \%$ and $5.5 \%$ respectively. In present study number of cases under HGUC comprised $50 \%$ of cases which is well within this range. Such a variation may be due to the difference in number of cases and duration of the study.

There has been wide variation in number of cases under infiltrating urothelial carcinoma category. Soumitra Das et $\mathrm{al}^{(6)}$ reported $58.3 \%$ of cases under this category. In our study $12.5 \%$ cases were reported under this category whereas Mohannad Hassan et $\mathrm{al}^{(9)}$ and Somaye zare et $\mathrm{al}^{(8)}$ didn't report any case under this category.

\section{Statistical Analysis}

The sensitivity of diagnosing UC in literature varies from $70 \%$ to $86.9 \%$. In our study the sensitivity was found to be $75 \%$, which was well within this range. Similar observation was seen by Sharada Rai et $\mathrm{al}^{(7)}$.

In our study specificity i.e. $87.5 \%$ was found close to Sharada rai et $\mathrm{al}^{(7)}$. In different studies this value ranged from $69.2 \%$ to $89.4 \%$.

Various studies found PPV to vary from $62.3 \%$ to $87.5 \%$. However, in our study PPV was quite high at $96 \%$.This value shows that there is good chance of detecting HGUC on urine cytology as per TPS. NPV was found to be less at $46.6 \%$, this may be because of small sample size and poor preservation of cells which came out to be negative on cytology (AUC) but positive on histopathology.

\section{Conclusion}

Urine cytology as reported by the Paris system will lead to uniform and unequivocal reporting of urothelial carcinoma.

\section{Bibliography}

1. Jemal A, Bray F, Center MM, Ferlay J, Ward E, Forman D. Global Cancer statistics. CA Cancer J Clin.2011;61: 6990 .
2. Murphy WM. Current Status of Urinary Cytology in the evaluation of Bladder Neoplasms. Human Pathology 1990, sept; 21(9): 886-896.

3. Guliz A. Barkan, Eva M. Wojcik, Ritu Nayar: The paris system for reporting urinary cytology: A quest to develop a standardized terminology 2016, June 18,60:185-197.

4. Moch H, Humphrey PA, Ulbright TM, Reuter VE. WHO classification of tumors of the Urinary System and Male Genital Organs. $4^{\text {th }}$ edition. France: International agency for research on Cancer (IARC); 2016

5. Chritopher L. Owens, Christopher J. VandenBussche, Frances H. Burroughs et al. A review of reporting systems and terminology for Urine Cytology. Cancer Cytopathol. 2013;121:9-14.

6. Soumitra Das, Anandi Roy Chowdhary, Supriya Basu. Evaluation of Urine Cytology in Urothelial Carcinoma with respect to The Paris System for Reporting Urine Cytology. Journal of Medical science and clinical research. 2017 November;461-470.

7. Sharada Rai, Bhagat S. Lali et al: Evaluation of The Paris System in Diagnosis of Urothelial Carcinomas. J. Cytol 2019;36:160-173.

8. Somaye Zare, MD, Leili Mirsadraei et al: A single institutional experience with The Paris System for reporting Urinary Cytology. Am J Clin Pathol 2018;150:162167.

9. Muhannad Hassan, MD, Sharaddha Solanki et al: Impact of Implementing the Paris System for reporting urine cytology in the performance of Urine cytology. Am J Clin Pathol 2016;146:384-390. 